\title{
Comparison of Tumor - Infiltrating Lymphocytes Between Primary and Metastatic Tumors in Her2+ and HER2-Breast Cancer Patients
}

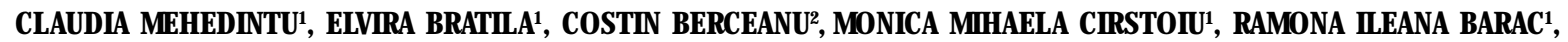 \\ CRISTINA VERONICA ANDREESCU ${ }^{1}$, DUMITRU CRISTINEL BADIU ${ }^{1}$, LAURENTIA GALES ${ }^{1}$ ANCA ZGURA ${ }^{1 *}$, \\ ADRIAN GHEORGHE BUMBU ${ }^{3}$ \\ ${ }^{1}$ Carol Davila University of Medicine and Pharmacy, 8 Eroii Sanitari Blvd., 050474, Bucharest, Romania \\ 2 University of Medicine and Pharmacy, 2 Petru Rares Str., 200349, Craiova, Romania \\ ${ }^{3}$ University of Oradea, Faculty of Medicine and Pharmacy, 10,1 Decembrie Sq., 410068, Oradea, Romania
}

\begin{abstract}
The impact of tumor infiltrating lymphocytes (TILS) on survival was confirmed in various cancer types. Our study aims to investigate the prognostic role of TILs on survival in patients with primary and metastatic tumors in breast cancer patients. We retrospectively identified 29 patients with human epidermal growth factor receptor - 2 (HER2+) and HER2 - early breast cancer diagnosed between 2012 and 2018 at Institute of Oncology Prof. Dr. Al. Trestioreanu Bucharest and who subsequently experienced regional or distant recurrence confirmed by tumor biopsy/resection.
\end{abstract}

Keywords: metastatic breast tumor, primary breast tumor, tumor-infiltrating lymphocytes, HER2, immune system

Breast cancer $(\mathrm{BC})$ is the second leading cause of cancer death in women [1,2]. It has been estimated that half of the new worldwide $\mathrm{BC}$ cases and $60 \%$ of the $\mathrm{BC}$ deaths occur in developing countries [3]. It occurs more frequentlyin elderly women and in most cases, risk factors are linked to estrogen hormone that stimulates breast tumor growth $[1,4-8]$. Tumor development is a heterogeneous process, making it difficult to evaluate the relationship between the tumor and the tumor microenvironment [9]. In breast cancer, the adaptive immune response can easily be seen in the infiltration of breast lesions from the time of benign breast atypia and with the increase in density due to invasive malignancy [10]. The presence of tumor-infiltrating lymphocytes (TILs) is associated with favorable with good prognostic in breast cancer [11,12]. TILs play an important role in mediating the response to chemotherapy and in improving all clinical outcomes in most subtypes of breast cancer [10].

Previous studies have reported that immune activation at the baseline, as assessed by pathology or gene expression arrays, is associated with a higher likelihood of pathological complete response after neoadjuvant chemotherapy (NAC) $[13,14]$, particularly in human epidermal growth factor receptor-2 (HER2)-positive and HER 2 negative breast cancers $[15,16]$. Furthermore, trastuzumab has been predicted to have beneficial effects. The presence of TILs in residual disease after neoadjuvant chemotherapy is associated with better prognosis breast cancers patients with HER2 negative [17-20]. This suggests that chemotherapy could convert low-TILs tumors into high-TILs tumors [21]. In the case of HER2 positive, even incremental increases in TILs inside and around the tumor were predictive in both the chemotherapy response and the improvement in patient survival rates [21-23].

This finding supports the concept that chemotherapy could partly exert its antitumor effect through the immune system [24]. Very little is known about the change in TILs during metastatic progression and the prognostic impact of TILs in metastatic sites $[25,26]$.
Our study aims to investigate the prognostic role of TILS on survival in patients with primary and metastatic tumors in breast cancer patients.

\section{Experimental part}

We retrospectively identified 29 patients with HER2-and HER2+ breast cancer diagnosed between 2012 and 2018 at Institute of Oncology Prof. Dr. Al. Trestioreanu, Bucharest and who subsequently experienced a regional or distant recurrence confirmed by tumor biopsy/resection.

All the tumor specimens were prepared for $H \& E$ staining and immunohistochemistry (IHC) and were reviewed by a pathologist. Immunohistochemistry was carried out using the following primary antibodies: anti estrogen receptor (ER), PR receptor and proliferation marker ( Ki67). The specimens were considered positive for hormone receptor if $\geq 1 \%$ of the cancer cells expressed ER. For the patients determined as HER2 ${ }^{+}$by IHC, FISH was used to confirm HER2 ${ }^{+}$disease.

The breast cancer subtypes were classified using IHC as previously described: HER2 positive or HER2 overexpressing $\left(H E R 2^{+}\right)$. Hematoxylin-eosin stained slides for the paired match cases were evaluated for stromal TILs by a pathologist. The specimens were classified into three groups: low TILs (<10\%), moderate TILs (10-60\%), and lymphocyte predominant breast cancer (LPBC) $(\geq 60 \%)$.

\section{Statistical analyses}

Associations of the percentage of between the primary and metastatic tumors were evaluated using Fisher's exact test for categorical variables and using the two-sided t-tests for continuous variables. The correlation between the percentages of TILs was calculated using Spearman's and Kendall's rank correlation coefficient test. In all the analyses, the differences were considered significant at $P$ $<0.05$.

The research meets the conditions of the ethical guidelines and legal requirements and was approved by each Ethical Committee of the Universities of Medicine 
and Pharmacy (see authors' affiliations). Informed consent was obtained from every patient included in the study.

\section{Results and discussions}

Medical files of 80 women diagnosed with breast cancer between 2010-2018 were retrospectively analyzed but only

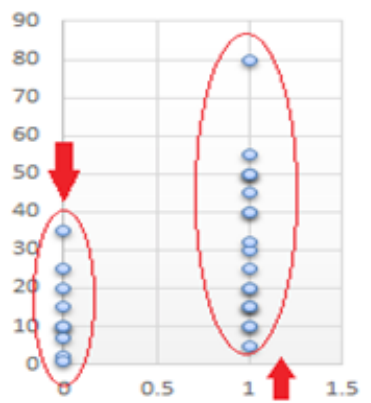

Fig1. Distribution of Ki67 for the sample of patients with regard to the HER groups
29 breast cancer patients presented the inclusion criteria in the study. Median age at diagnosis was 59.78 years, stage distribution was $10 \%, I A, 14 \%$ in stage IIB, $14 \%$ stage II $A$, $10 \%$ stage IIIB, $14 \%$ stage IIIC, and 38\% stage IV.

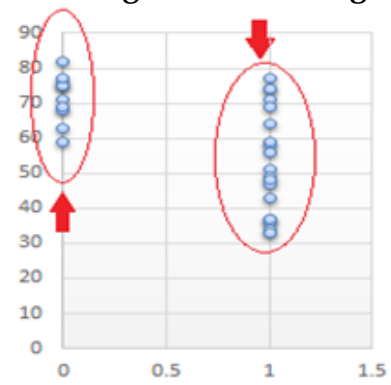

Fig 2. Distribution of age for the sample of patients with regard to the HER groups

Table 1

AGE DIFFERENCE BETWEEN HER GROUPS

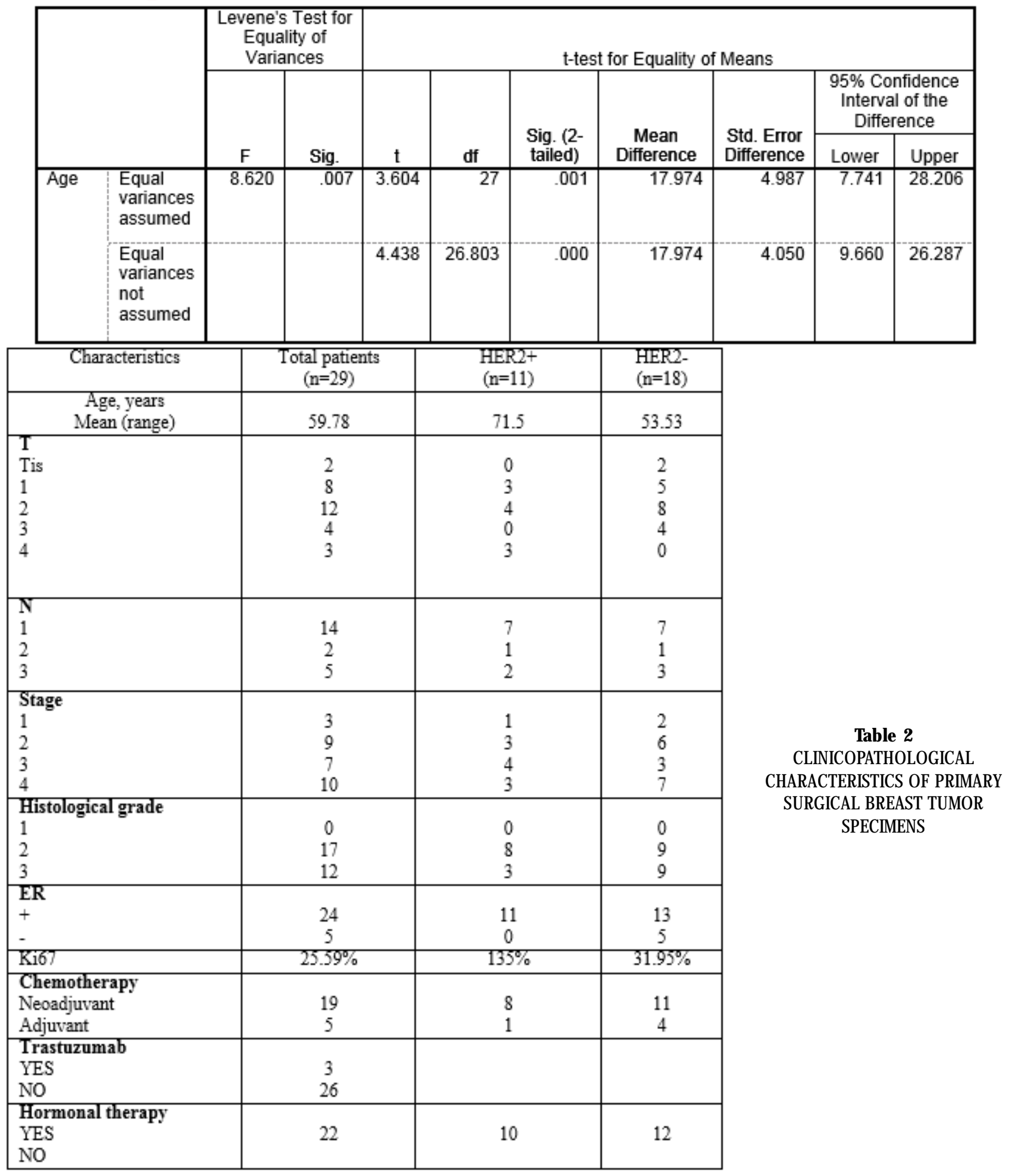


Of all breast cancer patients, 38\% represented HER2 positive patients and $62 \%$ HER 2 negative patients, 5 patients are TNBC. Ki 67 percentage ranged between 1\% and $80 \%$ (median was $25.59 \%$ ). We didn't find any statistical correlation between age and Ki67 level (fig.1). As reported in table 1 young patients had HER2-. The characteristics of the 29 breast cancer patients at the time of diagnosis of the primary breast cancer are presented in table 2 . We evaluated the core needle biopsy and surgical specimens before received neoadjuvant chemotherapy for excluding the possibility of alterations in the immune microenvironments of the tumors caused by the therapy.

Most of the patients received neoadjuvant systemic treatment ( $85 \%$ of patients received chemotherapy, $27 \%$ of HER2+ patients received trastuzumab). The first biopsy sites of the metastatic tumors were the skin $(n=2)$, brain

Table 3

DISTRIBUTION OF PATIENTS REGARDING TILS LEVELS FOR HER2AND FOR HER2+

\begin{tabular}{|c|c|c|}
\hline \multirow{2}{*}{ Tils } & HER2+ & HER2- \\
\cline { 2 - 3 } & \multicolumn{2}{|c|}{$\%$} \\
\hline Low & 40 & 42.1 \\
\hline Intermediate & 50 & 47.4 \\
\hline High & 10 & 5.3 \\
\hline
\end{tabular}

\begin{tabular}{|c|c|c|c|}
\hline Subtype & $\begin{array}{c}\text { First site of } \\
\text { biopsy }\end{array}$ & $\begin{array}{c}\text { Primary tumor } \\
\text { TILs }\end{array}$ & $\begin{array}{c}\text { Metastatic tumor } \\
\text { TILs }\end{array}$ \\
\hline \multirow{3}{*}{ HER2+ } & Lung & low & low \\
& low & low \\
& intermediate & low \\
& Liver & intermediate & low \\
& Brain & intermediate & low \\
& Brain & low & low \\
\hline & Lung & low & low \\
& Lung & low & low \\
& Skin & intermediate & intermediate \\
& Skin & intermediate & intermediate \\
& Bone & intermediate & intermediate \\
& & low \\
& & &
\end{tabular}

\begin{tabular}{|c|c|c|c|c|c|c|c|c|}
\hline & & & varsta & TILS1 & HER & KI67 & ER & TILS2 \\
\hline \multirow{6}{*}{$\begin{array}{c}\text { Kendall's } \\
\text { tau_b }\end{array}$} & varsta & $\begin{array}{l}\text { Correlation } \\
\text { Coefficient }\end{array}$ & 1.000 & -.057 & $-.479^{-}$ & -.213 & -.190 & -.112 \\
\hline & TILS1 & $\begin{array}{l}\text { Correlation } \\
\text { Coefficient }\end{array}$ & -.057 & 1.000 & -.101 & -.094 & .175 & -.208 \\
\hline & HER & $\begin{array}{l}\text { Correlation } \\
\text { Coefficient }\end{array}$ & $-.479^{-}$ & -.101 & 1.000 & $.423^{-}$ & $.487^{\circ}$ & .096 \\
\hline & $\mathrm{K} 167$ & $\begin{array}{l}\text { Correlation } \\
\text { Coefficient }\end{array}$ & -.213 & -.094 & $.423^{-}$ & 1.000 & .278 & .132 \\
\hline & ER & $\begin{array}{l}\text { Correlation } \\
\text { Coefficient }\end{array}$ & -.190 & .175 & $.487^{\circ}$ & .278 & 1.000 & .145 \\
\hline & TILS2 & $\begin{array}{l}\text { Correlation } \\
\text { Coefficient }\end{array}$ & -.112 & -.208 & .096 & .132 & .145 & 1.000 \\
\hline \multirow{6}{*}{$\begin{array}{c}\text { Spearman' } \\
\text { s rho }\end{array}$} & varsta & $\begin{array}{l}\text { Correlation } \\
\text { Coefficient }\end{array}$ & 1.000 & -.068 & $-.573^{-}$ & -.270 & -.227 & -.137 \\
\hline & TILS1 & $\begin{array}{l}\text { Correlation } \\
\text { Coefficient }\end{array}$ & -.068 & 1.000 & -.106 & -.115 & .182 & -.224 \\
\hline & HER & $\begin{array}{l}\text { Correlation } \\
\text { Coefficient }\end{array}$ & $-.573^{\circ}$ & -.106 & 1.000 & $.497^{+}$ & $.487^{\circ}$ & .099 \\
\hline & $\mathrm{K} 167$ & $\begin{array}{l}\text { Correlation } \\
\text { Coefficient }\end{array}$ & -.270 & -.115 & $.497^{\circ}$ & 1.000 & .327 & .169 \\
\hline & ER & $\begin{array}{l}\text { Correlation } \\
\text { Coefficient }\end{array}$ & -.227 & .182 & $.487^{\circ}$ & .327 & 1.000 & .149 \\
\hline & TILS2 & $\begin{array}{l}\text { Correlation } \\
\text { Coefficient }\end{array}$ & -.137 & -.224 & .099 & .169 & .149 & 1.000 \\
\hline
\end{tabular}

http://www.revistadechimie.ro
Table 4

TUMOR-INFILTRATING LYMPHOCYTES (TILS) BETWEEN PRIMARY AND METASTATIC BREAST CANCER TUMORS FOR EACH SUBTYPE

Table 5

CORRELATIONS BETWEEN ANALYZED VARIABLES 


\begin{tabular}{|c|l|c|c|c|c|c|}
\hline \multicolumn{7}{|c|}{ Descriptive Statistics } \\
\hline \multicolumn{2}{|c|}{ TILS1 } & N & Minimum & Maximum & Mean & Std. deviation \\
\hline 1 & Months & 12 & 2 & 75 & 19.08 & 21.008 \\
\hline 2 & Months & 13 & 3 & 62 & 16.15 & 16.921 \\
\hline 3 & Months & 2 & 15 & 20 & 17.50 & 3.536 \\
\hline
\end{tabular}

Table 6

DESCRIPTIVE STATISTICS FOR THE MONTHS INDICATOR BASED ON TILS LEVELS

Table 7

STATISTICAL DIFFERENCE FOR MONTHS VARIABLE BETWEEN TILS (1 AND 2) GROUPS

Independent Samples Test

\begin{tabular}{|c|c|c|c|c|c|c|c|c|c|}
\hline & \multicolumn{2}{|c|}{ Equality of Variances } & \multicolumn{7}{|c|}{ t-test for Equality of Means } \\
\hline & \multirow[t]{2}{*}{$\mathrm{F}$} & \multirow[t]{2}{*}{ Sig. } & \multirow[t]{2}{*}{$\mathrm{t}$} & \multirow[t]{2}{*}{ df } & \multirow{2}{*}{$\begin{array}{l}\text { Sig. (2- } \\
\text { tailed) }\end{array}$} & \multirow{2}{*}{$\begin{array}{c}\text { Mean } \\
\text { Difference }\end{array}$} & \multirow{2}{*}{$\begin{array}{l}\text { Std. Error } \\
\text { Difference }\end{array}$} & \multicolumn{2}{|c|}{$\begin{array}{l}95 \% \text { Confidence } \\
\text { Interval of the } \\
\text { Difference }\end{array}$} \\
\hline & & & & & & & & Lower & Upper \\
\hline $\begin{array}{l}\text { Equal } \\
\text { variances } \\
\text { assumed }\end{array}$ & .342 & .564 & .385 & 23 & .703 & 2.929 & 7.600 & -12.793 & 18.652 \\
\hline $\begin{array}{l}\text { Equal } \\
\text { variances } \\
\text { not } \\
\text { assumed }\end{array}$ & & & .382 & 21.162 & .706 & 2.929 & 7.668 & -13.010 & 18.869 \\
\hline
\end{tabular}

The mean follow-up of patients who had Tils low was 19.08 month, for Tils intermediate was 16.15 and for high was 17.5 months.

Although many adjuvant and neoadjuvant studies have assessed infiltrating lymphocytes and stromal lymphocytic infiltration has been found to constitute a robust prognostic factor in primary HER2+ tumors or HER2- breast cancers, whether lymphocytic infiltration in metastatic tumors could be a prognostic factor has not yet been evaluated $[1,6,22,27]$. In our study, only a patient with low TILs in metastatic tumors had a significantly lower OS than the patiences with intermediate TILs. Our results suggest that the patients with high or intermediate TILs may have a better, even in metastatic tumors.

This article reports the assessment of comparison of tumor infiltrating lymphocytes between primary and metastatic tumors.

It is now recognized that patients with HER2+ and HER2 negative early breast cancer with high levels of TILS on primary tumor have a lower recurrence rate, therefore suggesting that breast cancer recurrences might be enriched in low TILs tumors [1,28]. Moreover, previous reports showed lower TILs levels in secondary lesions as compared to primary tumors $[1,6,29,30]$. In our study, TILs were generally intermediate. We only found a nonsignificant decrease in TILs from primary to metastasis in the HER2 negative patients of our study, however, the sample size of patients with matched samples was small because it is difficult to detect TILs in nodes.

We observed that host-dependent factors are associated with TILs on metastasis. In particular, younger women showed lower levels of TILs than older patients. We found in our study that the characteristics of the tumor immune infiltrate may be different across metastatic sites. We observed the lowest TILs levels in lung and brain metastasis and the intermediate levels in skin secondary lesions and we did not observe any favorable impact of high TILs on OS in HER2+ breast cancer patients. We did not notice changes in metastasis TILs levels for patients receiving neo adjuvant or adjuvant therapy.

\section{Conclusions}

Tumor-infiltrating lymphocytes are associated with a better neoadjuvant chemotherapy response and prognosis in HER2+ and HER 2- breast cancers. Most of TILs levels on metastasis were low and did not differ between HER2and HER2+ tumors. Younger patients showed significantly lower TILs. In TNBC patients, TILs were intermediate compared with HER2 + patients. The relationship between the immune system and HER2+ and HER2-breast cancer deserve further exploration in the metastatic settings.

\section{References}

1.OGIYA, R., NIIKURA, N., KUMAKI, N., BIANCHINI, G., KITANO, S, IWAMOTO, T., et al., Cancer sci., 107, no. 2, 2016, p. 1730.

2.SAVAS, P., SALGADO R, DENEKERT, C., SOTIRIOU, C., DARCY, P.K., SMYTH, M.J, et al., Nat. Rev. Clin. Oncol., 13, no. 4, 2016, p. 228.

3.DIECI, M.V., CRISCTIELLO, C., GOUBAR, A., VIALE, G., CONTE, P., GUARNERI, V., et al., Ann. Oncol., 25, no. 3, 2014, p. 611.

4.TIT, D.M., BUNGAU, S., IOVAN, C., NISTOR CSEPPENTO, D.C., ENDRES, L., SAVA, C., SABAU, A.M., FURAU, G., FURAU, C., J CM, 7, no. 10, 2018, p. 297.

5.TIT, D.M., PALLAG, A., IOVAN, C., FURAU, G., FURAU, C., BUNGAU, S., Iran. J. Public Health, 46, no. 11, 2017, p. 1128.

6. DIECI, M.V., TSVETKOVA, V., ORVIETO, E., PIACENTINI, F., FICARRA, G., et al., Breast Cancer Res., 20, 2018, p. 62.

7.BUMBU, A., PASCA, B., TIT, D.M., BUNGAU, S., BUMBU, G., Farmacia, 64, no. 3, 2016, p. 419.

8.BUMBU, A., NACER, K., BRATU, 0.; et al., Proceedings of the 14th National Congress of Urogynecology and the National Conference of the Romanian Association for the Study of Pain, 2017, p. 82.

9.SALGRADO, R., DENEKERT, C., DEMARIA, S., SIRTAINE, N., KLAUSCHEN, F., PRUNERI, G., et al., Ann. Oncol., 26, no. 2, 2015, p. 259.

10.STANTON, S.E., DISIS, M.L., J. Immunother. Cancer., 4, 2016, p. 59. 11.LOI, S., SIRTAINE, N., PIETTE, F., SALGADO, R., VIALE, G., VAN EENOO, F., et al. BIG 02-98 J. Clin. Oncol., 31, no. 7, 2013, p. 860. 12.ENDRES, L., UIVAROSAN, D., TIT, D.M., POP, O., BUNGAU S., BUHAS C., Iran. J. Public Health, 47, no. 4, 2018, p. 606.

13.DENARDO, D.G., COUSSENS, L., Breast Cancer Res., 9, no. 4, 2007, p. 212.

14.SCHMIDT, M., BOHM, D., VON TORNE, C. et al., Cancer Res., 68, 2008, p. 5405. 
15.DENEKERT, C., LOIBL, S., NOSKE, A. et al. J. Clin. Oncol., 28, no.1, 2010, p. 105.

16.WEST, N.R, MILNE, K., TRUONG, P.T., MACPHERSON, N., NELSON, B.H., WATSON, P.H., Breast Cancer Res., 13, no. 6, 2011, p. 126. 17.BRATU, O.G., MARCU R.D., SOCEA, B., NEAGU, T.P., DIACONU, C.C., SCARNECIU, I., TURCU, F.L., RADAVOI, G.D., BRATILA, E., BERCEANU, C., SPINU, A.D., Rev. Chim. (Bucharest), 69, no. 7, 2018, p. 1813.

18.ONO, M., TSUDA, H., SHIMIZU, C. et al. Breast Cancer Res. Treat., 132, 2012, p.793.

19.YAMAGUCHI, R., TANAKA, M., YANO, A. et al., Hum. Pathol., 43, 2012, p. 1688.

20.LEE, H.J ., SEO, J.Y., Ahn, J.H., Ahn, S.H., Gong, G., J. Breast Cancer, 16, no.1, 2013, p. 32.

21.ADAMS, S., GRAY, R.J ., DEMARIA, S. et al., J. Clin. Oncol., 32, 2014, p. 2959.

22.LOI, S., MICHIELS, S., SALGADO, R., SIRTAINE, N., JOSE, V., FUMAGALLI, D., et al. Ann Oncol., 25, no. 8, 2014, p. 1544.
23.DIECI, M.V., MATHIEU, M.C., GUARNERI, V., CONTE, P., DELALOGE, S., ANDRE, F., et al., Ann. Oncol. 26, no 8, 2015, p. 1698.

24.DENEKERT, C., VON MINCKWITZ, G., BRASE, J.C., et al., J. Clin. Oncol., 33, 2014, p. 983.

25.URSULESCU, C.L., URSARU, M., CIOBANU, D., NEGRU, D., LUPASCU, C., Rev. Chim. (Bucharest), 68, no. 5, 2017, p. 1143.

26.PEREZ, E.A., THOMPSON, E.A., BALLMAN, K.V. etal., J. Clin. Oncol., 33, 2015, p. 701.

27.LEONG, P.P., MOHAMMAD, R., IBRAHIM, N., et al., Immunol. Lett., 102, 2006, p. 229.

28.MIYASHITA, M., SASANO, H., TAMAKI, K., et al., Breast Cancer Res. Treat., 148, 2014, p. 525.

29.BURSTEIN, H.J., LACCHETTI, C., ANDERSON, H., et al. J. Clin. Oncol., 34, 2016, p. 1689.

30.CIMINO-MATHEWS, A., Ye X, MEEKER, A., ARGANI, P., EMENS, L.A., Hum. Pathol., 44, 2013, p. 2055.

$\overline{\text { Manuscript received: } 18.03 .2018}$ 